\title{
COMPARATIVE STABLE ISOTOPES STUDY OF THE MAGNESITE DEPOSITS OF GREECE
}

\author{
Gartzos E.
}

Agricultural University of Athens, Department of Sciences, Division of Geological Sciences and Atmospheric Environment, lera Odos 75, 11855 Athens, Greece, egartz@aua.gr,

\section{ABSTRACT}

The magnesite deposits of North Evia, Lesvos and Chalkidiki, which are hosted by Alpine type ultramafic rocks, have been studied from an isotopic point of view and are compared with similar magnesite deposits occurring in other countries of central-southeastern Europe and Turkey.

Magnesites from N. Evia, Lesvos and Chalkidiki have similar isotopic compositions. They have

$\delta^{13} \mathrm{C}_{\mathrm{PDB}}$ values ranging from $-8.6 \%$ to $-14.8 \%$ and $\delta^{18} \mathrm{O}_{\mathrm{Smow}}$ values ranging from $24.0 \%$ o to 30.1 $\%$, which indicate a rather similar formation process for all three areas.

The studied Greek magnesite deposits have similar isotopic compositions with vein and stockwork type magnesite deposits from: Turkey (Koyakci Tepe, vein and stockwork types; Helvacibaba, stockwork type), Poland (vein type), and Former Yugoslavia (vein type).

There is strong isotopic evidence that meteoric water is involved in the formation of the stockwork and vein type magnesite deposits of all four countries, including Greece. There is also isotopic evidence for the organic origin of carbon participating in the carbonates (magnesites) of these deposits.

\section{INTRODUCTION}

North Evia and Chalkidiki are the major magnesite producing areas of Greece. There have been numerous studies on the magnesite deposits of Evia, Lesvos, Chalkidiki and similar magnesite deposits all over the world hosted by ultramafic rocks (Petraschech 1964, Capedri \& Rossi 1973, Dabitzias 1980). Two independent studies on the magnesite deposits of Chalkidiki (Vavdos), the first by Dabitzias (1981) and the second by Burgath et al. (1981), suggested different origin for the same magnesite deposits, as hydrothermal or as weathering products, respectively. These studies reveal a general controversy on the origin of magnesite, persisting even today, in which weathering versus hydrothermal origin is debated. The magnesite problem becomes more complicated as Illic (1968) suggested that medium- to large-sized veins of magnesite, which occur at deeper level, are hydrothermal while isolated near-surface nodules and subspherical bodies of magnesite are products of weathering. Suggested temperatures for the precipitation of magnesite range from 10 to $400^{\circ} \mathrm{C}$. Pohl (1990) discussed and summarized models and trends concerning the genesis of magnesite deposits.

Gartzos $(1986,1990)$ on the basis of geochemical - isotopic data and vein petrography studies suggested that the magnesite deposits of $\mathrm{N}$. Evia were formed from mixing of descending meteoric water with ascending $\mathrm{CO}_{2}$ at temperatures $<60^{\circ} \mathrm{C}$. Barnes et al. (1986) presented interesting stable isotopes data concerning the origin of thermal and cold meteoric waters and dissolved bicarbonates occurring in the Peri - Aegean region (Fig. $1 \& 2$, Tab. 1). These data have been used in the present study in order to investigate the nature of the aqueous solutions, which were involved in the genesis of the studied magnesite deposits.

The last decade a lot of magnesite stable isotopes data have been accumulated, which could support a comparative study for a better understanding of the origin of carbon and involved water.

In the present study, the magnesite deposits of N. Evia, Lesvos, and Chalkidiki (Fig.1) are studied and compared from a stable isotopes point of view. They are also compared with similar 
magnesite deposits from other countries. The origin of carbon and the type of the waters (aqueous fluids) involved are inferred from stable isotopes data.

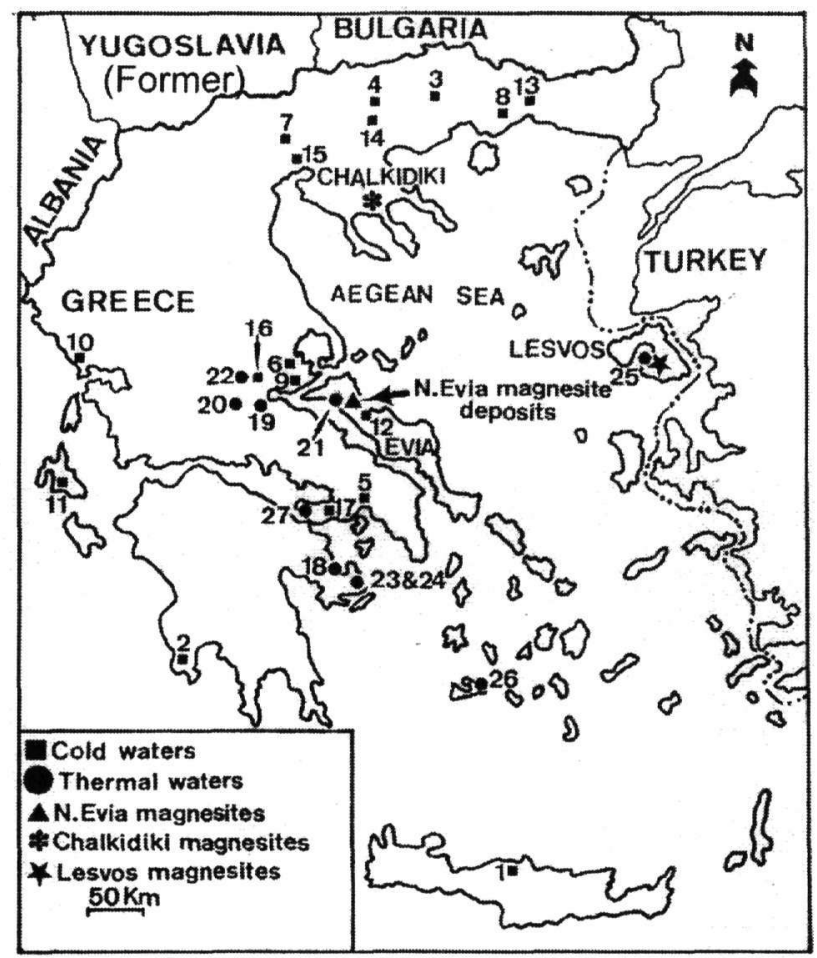

Figure 1. Map of Greece showing the magnesite deposits of Evia, Lesvos and Chalkidiki plus sampling locations of the reported cold meteoric waters and thermal waters.

\section{GEOLOGICAL SETTING}

The areas of N. Evia, Lesvos and Chalkidiki are highly faulted due to extentional tectonics prevailing in the Aegean and peri-Aegean region during the last 13 million years (Le Pichon \& Angelier 1979). The magnesite deposits occur in ultramafic rocks and are closely associated with these faults. The most important deposits are hosted by non or partly serpentinized peridotites, which usually have been altered to brown serpentinite (a rock composed mainly of carbonates, quartz, limonite and serpentine) at the sites of intense mineralization or towards the contacts of some veins. The known deposits are restricted to shallow depths (maximum depth is about $250 \mathrm{~m}$ ). In all three areas there is a considerable amount of ophiolites, which have been overthrusted on Mesozoic platform carbonates. They are dismembered ophiolites with missing upper units. Sheeted dyke complexes, pillow lavas, and sediments have been either sheared off or weathered out (Guernet 1971, Caperdi 1974, Dabitzias 1980, Gartzos 1986, Gartzos et al. 1994, Serelis \& Gartzos 1994).

\section{TYPE OF MINERALIZATION}

Magnesite is cryptocrystalline with crystals $1-5 \mu \mathrm{m}$ large. It is usually snow white, shows conchoidal fracture and resembles unglazed porcelain. On the basis of the type of mineralization three main types of magnesite deposits were distinguished: 
a. Nodular aggregates of magnesite replacing the host rock. Very often, coalesced nodules form irregular to roughly subspherical bodies of magnesite varying from a few $\mathrm{cm}$ to a few meters in diameter. They usually occur at higher horizons (nearsurface).

b. Fracture - filling magnesite, which occurs as veins along faults, joints and other fractures. The veins, which occur at the upper parts of the deposits (near-surface) are thin and usually form dense networks (stockwork - type deposits). Medium sized veins $(5-25 \mathrm{~cm})$ and larger ones $(25-100 \mathrm{~cm})$ occur at deeper levels. The majority of the veins have nodular structure.

c. Lens - like bodies of magnesite ( 1 to $4 \mathrm{~m}$ wide and 5 to $12 \mathrm{~m}$ long) formed by coalescence of nodules in dilatation zones of pinch - and - swell structures. They are located at deeper horizons.

\section{MATERIALS AND METHODS}

Magnesites and dolomites associated with the peridotites and serpentinites of North Evia, Lesvos and Chalkidiki were sampled and analyzed for their $\delta^{13} \mathrm{C}$ and $\delta^{18} \mathrm{O}$ isotopic compositions. The samples of dolomite are from Evia where dolomite has been formed by replacement of magnesite and serpentine.

All samples were reacted with phosphoric acid at $50^{\circ} \mathrm{C}$. The isotope ratios were determined on a VG Micromass 903 triple collector mass spectrometer at the stable isotopes laboratory of the ETH in Zurich. The samples were measured against the Carrara Marble laboratory standard. Carbon isotopes ratios of the carbonates are reported in permil deviations relative to the Chicago PDB standard, whereas oxygen isotopes ratios are given relative to SMOW.

The oxygen and carbon isotope compositions of the analyzed carbonates are presented in table 1 and are shown in figure 2 . Identical results were obtained from samples SOT. $1^{*}$ and SOT. $1^{\star *}$ which represent two independent analyses of powder prepared from hand specimen SOT.1 and reacted separately.

\section{ISOTOPIC RESULTS}

The $\delta$-values (vs SMOW) of the oxygen isotopes of the magnesites from $\mathrm{N}$. Evia, Lesvos and Chalkidiki range from 24.0 to $30.1 \%$ o, and carbon isotopes $\delta$-values (vs PDB) vary from -8.6 to $-14.8 \%$ (Tab. 1). These $\delta$-values correspond to magnesite values, which O'Neil \& Barnes (1971) consider to represent isotopic equilibrium with their formation waters as they plot in the equilibrium field defined by them (Fig. 2B). The field has been defined on the basis of isotopic data from carbonates associated with ultramafic rocks occurring along the central and northern Coast Ranges of California (Barnes \& O`Neil 1971, Barnes et al. 1973).

Table 1. $\delta^{18} \mathrm{O}_{\text {SMOW }}$ and $\delta^{13} \mathrm{C}_{\mathrm{PDB}}$ values of magnesites and dolomites from $\mathrm{N}$. Evia, Lesvos and Chalkidiki.

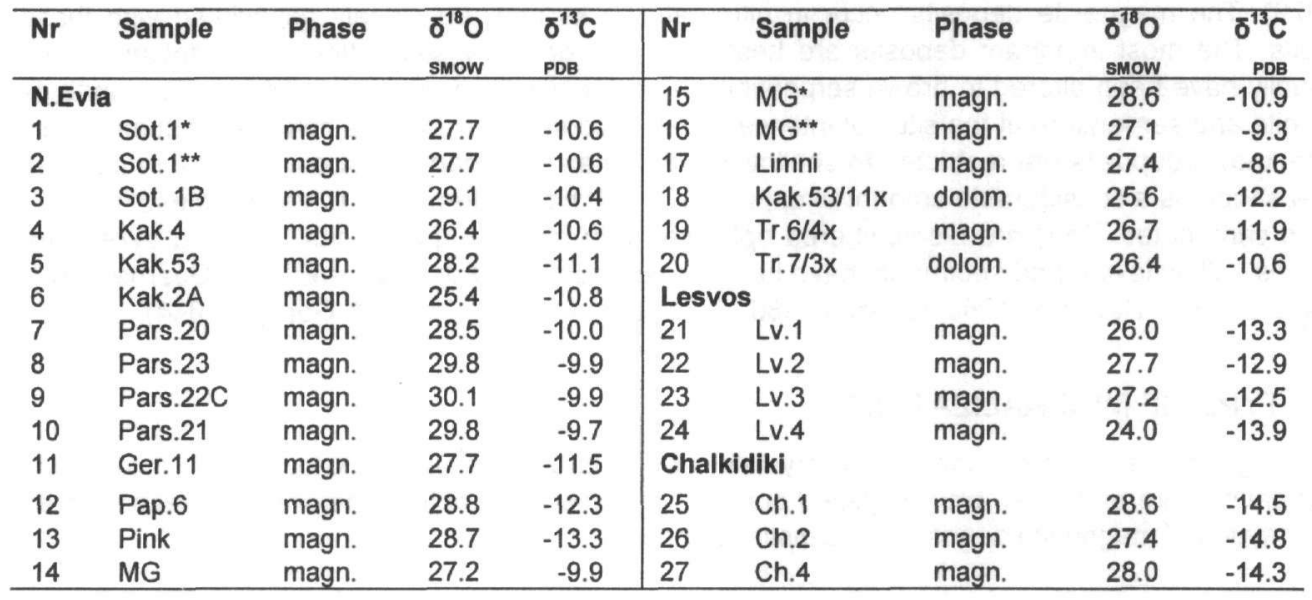




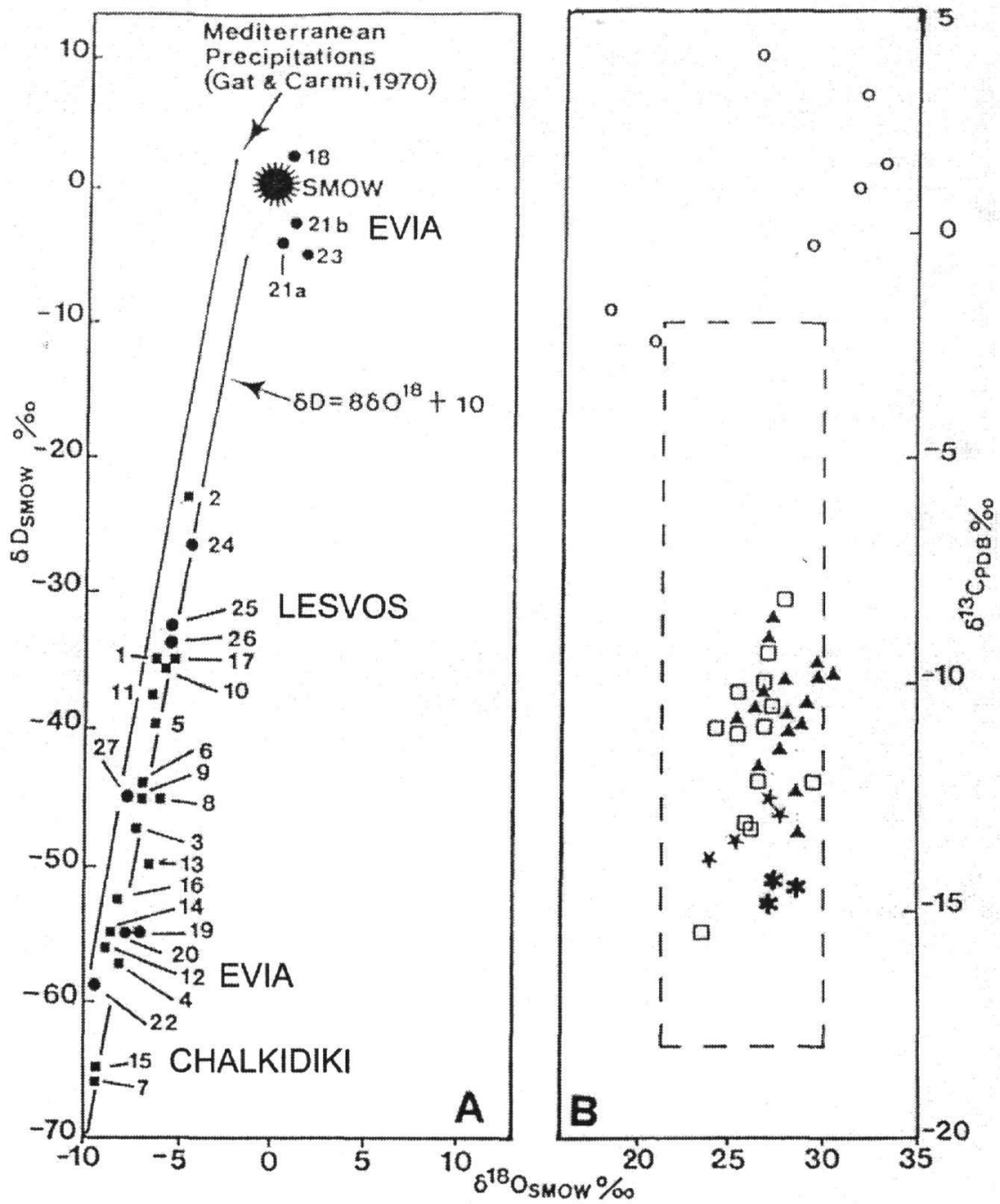

Figure 2. A: Plot of the peri-Aegean thermal waters $(\bullet)$ and cold meteoric waters $(\bullet)$ in the $\delta \mathrm{D}$ vs $\delta^{18} \mathrm{O}$ diagram. B: Correlation plot between carbon and oxygen isotopes contained in the $\mathrm{HCO}_{3}{ }^{-}$of thermal (o) and cold ( $\square$ ) waters and in the magnesites of N. Evia $(\mathbf{\Lambda})$, Lesvos $(\star)$ and Chalkidiki $(*)$. Symbols as in figure 1.

\section{ORIGIN OF WATER AND CARBON}

\subsection{Thermal and cold waters of the Aegean and Peri-Aegean area}

It was mentioned earlier that magnesite is a common fracture filling phase in the ultramafic rocks of N. Evia, Lesvos and Chalkidiki. These host rocks show a typical "brown alteration". These observations make clear that magnesite has been formed by waters circulating through the ultramafic rocks.

Waters occurring in mineralized and nonmineralized ultramafic rocks of Evia, Lesvos and Chalkidiki, and other localities of the peri-Aegean area have been studied by Papastamataki \& Leonis (1982), Barnes et al. (1986), Gartzos (1986), Gartzos \& Stamatis (1996). These waters have been plotted on the $\delta \mathrm{D}$ vs $\delta^{18} \mathrm{O}$ diagram shown in figure $2 \mathrm{~A}$. The cold meteoric waters are samples from: (a) meteorological stations and (b) cold springs and rivers which are supposed to represent 
homogenized local meteoric waters. The thermal waters include samples from: (a) thermal springs and (b) exploration boreholes in hydrothermal fields.

The cold meteoric waters plot along the meteoric water line $\delta D=8 \delta 0^{18}+10$ (Craig 1963). Their $\delta^{18} \mathrm{O}_{\text {SMow }}$ permil values range from -9.5 to -4.3 (mean value $=-7.2$ ). The magnesites from Evia, Lesvos and Chalkidiki, which are shown in figure $2 \mathrm{~B}$ have $\delta^{18} \mathrm{O}_{\text {SMow }}$ permil values ranging from 24.0 to 30.1 (mean value $=27.7$ ).

Assuming equilibrium fractionation between magnesite and meteoric water, a fractionation of about 35 is estimated from figure 2. Similar fractionation of about 34 at $12^{\circ} \mathrm{C}$ (mean temperature of cold meteoric waters) has been obtained from the equation of O'Neil \& Barnes (1971). Unfortunately experimental isotopic data for the system $\mathrm{MgCO}_{3}-\mathrm{H}_{2} \mathrm{O}$ are lacking. However, the compiled 1000. In. $\alpha$ vs T curves (Friedman \& $O^{\prime}$ Neil, 1977) for the fractionation of $O^{18}$ between alkaline earth carbonates and water can serve as a crude guide for the magnesite - water system. This is justified by the fact that the $\mathrm{O}^{18}$ fractionation curves (1000.In. $\alpha$ vs $\mathrm{T}$ ) of all the experimentally determined carbonate - water systems $\left(\mathrm{BaCO}_{3}-, \mathrm{SrCO}_{3}-, \mathrm{CaCO}_{3}\right.$ - and $\left.\mathrm{CaMg}\left(\mathrm{CO}_{3}\right)_{2}-\mathrm{H}_{2} \mathrm{O}\right)$ show parallel trend and plot close to each other. Thus, in analogy, the fractionation curve of magnesite is expected to plot very close to the curve of dolomite in a parallel trend. Assuming that the above approximation is correct a fractionation in the range from 33 to 36 is predicted for the magnesite - water system at $12^{\circ} \mathrm{C}$. This range is of the same order of magnitude with the magnesite - cold water fractionation estimated from both, figure 2 and the equation of $\mathrm{O}^{\prime}$ Neil \& Barnes (1971).

The thermal waters (mean temperature $=50^{\circ} \mathrm{C}$ ) have been also plotted in figure 2 . On the basis of hydrochemical analyses and isotopic data the following were suggested concerning the origin of the thermal waters (Barnes et al. 1986; Gartzos \& Stamatis 1996). Sample 22 is a low TDS ( $<1000$ ppm) thermal water, which contains 20 ppm Cl . It is heated local meteoric water. Samples 19, 20, and 24-27 are high TDS (>1000 ppm) thermal waters with $\mathrm{Cl}^{-}$ranging from $970 \mathrm{ppm}$ to $4700 \mathrm{ppm}$. They were generated by mixing of ascending hot sea water with descending local meteoric water. The contribution of seawater ranges from $10 \%$ to $25 \%$. Samples $18,21 \mathrm{a}, 21 \mathrm{~b}$ and 23 are also high TDS thermal waters but with $\mathrm{Cl}^{-}$ranging from $18970 \mathrm{ppm}$ to $21985 \mathrm{ppm}$. The contribution o seawater ranges from $92 \%$ to $100 \%$. These waters plot very close to SMOW (Fig. 2A).

Thermal water $\delta^{18} \mathrm{O}_{\text {SMow }}$ permil values range from -9.5 to 1.0 (mean value $=-4.0$ ). Figure $2 \mathrm{~A}$ shows that the thermal waters with low $\delta^{18} \mathrm{O}_{\text {Smow }}$ values plot in the cold meteoric water field. However, considering the mentioned curves showing the fractionation of $\mathrm{O}^{18}$ between alkaline earth carbonates and water at various temperatures (Friedman \& O'Neil, 1977), as well as the above mentioned equation of $O^{\prime}$ Neil \& Barnes (1971), a drastic fractionation decrease with increasing temperature is expected. At $50^{\circ} \mathrm{C}$ (mean temperature of thermal waters at the site of discharge earth surface) a fractionation of about 26 is expected. However, depth temperatures $>100^{\circ} \mathrm{C}$ have been reported by Papastamataki \& Leonis (1982) for the high $\delta^{18} \mathrm{O}$ thermal waters. At $100^{\circ} \mathrm{C}$ fractionation is expected even smaller, about 22. Magnesites formed from these thermal waters are expected to have different $\delta^{18} \mathrm{O}_{\mathrm{Sm}}$ w values from those observed in the magnesites of $\mathrm{N}$. Evia, Lesvos and Chalkidiki. They are expected to range from 16.5 to 23.0 permil, assuming stronger fractionation between magnesite and low $\delta^{18} \mathrm{O}$ water $\left(-9.5+26.0=16,5 \delta^{18} \mathrm{O}_{\mathrm{Smow}}\right.$ permil) and weaker fractionation between magnesite and high $\delta^{18} \mathrm{O}$ water of higher temperature $(1.0+22.0=23.0$ $\delta^{18} \mathrm{O}_{\text {smow }}$ permil).

All the above relations and indications suggest that a meteoric origin for the water involved in the genesis of magnesite should be considered seriously.

\section{2 $\mathrm{HCO}_{3}{ }^{-}$in thermal and cold waters of the peri-Aegean region.}

Cold waters occurring in the peri-Aegean area contain bicarbonates with $\delta^{13} \mathrm{C}_{\mathrm{PDB}}$ values from -8.0 to $-15.5 \%$ and $\delta^{18} \mathrm{O}_{\text {SMOW }}$ from 24.5 to about $30.0 \%$, which are in the same range with

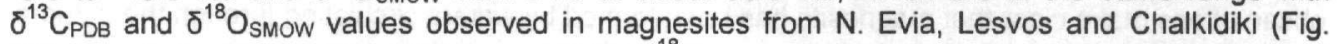
2B). Thermal water bicarbonates have similar $\delta^{18} \mathrm{O}_{\text {SMow }}$ values, but they can be distinguished by the different $\delta^{13} \mathrm{C}_{\mathrm{PDB}}$ values.

Barnes et al. (1986) suggest that $\delta^{18} \mathrm{O}$ of $\mathrm{HCO}_{3}{ }^{-}$is controlled by $\delta^{18} \mathrm{O}$ of $\mathrm{H}_{2} \mathrm{O}$ in both thermal and cold waters. This is expected because the oxygen reservoir of the water is very large and controls the small oxygen reservoir of the dissolved $\mathrm{HCO}_{3}{ }^{-}$. On the contrary, $\mathrm{H}_{2} \mathrm{O}$ itself has no carbon and the aqueous species of carbon form a small carbon reservoir in the aqueous solutions. Varia- 
tions in the carbon sources themselves or in their relative contribution will affect the $\mathrm{C}^{13} / \mathrm{C}^{12}$ ratios of both, the aqueous species of carbon and the formed magnesites. Such seems to be the case in our study area. Consequently, the carbon isotopes only can serve as indicators of sources.

Fractionation of $\mathrm{C}^{13}$ between alkaline earth carbonates and $\mathrm{HCO}_{3}{ }^{-}$is expected to be very low at cold-water temperatures. Reported relevant experimental data by Emrich et al. (1970) indicate the following fractionation factors for the system calcite $-\mathrm{HCO}_{3}{ }^{\circ}: 1.001$ at $12^{\circ} \mathrm{C}, 1.003$ at $50^{\circ} \mathrm{C}$ and 1.0042 at $100^{\circ} \mathrm{C}$. Consequently, cold meteoric waters are expected to precipitate magnesite with $\delta^{13} C_{\text {PDB }}$ values similar or very close to those observed in the dissolved bicarbonates.

On the contrary, thermal water bicarbonates have much higher $\delta^{13} \mathrm{C}_{\mathrm{PDB}}$ values (Fig. $2 \mathrm{~B}$ ). In addition, the magnesite $-\mathrm{HCO}_{3}{ }^{-}$fractionation is expected to be higher due to the higher temperatures of the thermal waters. Consequently, magnesites formed from these waters are expected to have relatively high $\delta^{13} \mathrm{C}_{\mathrm{PDB}}$ values, about $5 \%$.

Concerning the negative $\delta^{13} \mathrm{C}_{\mathrm{PDB}}$ values of the bicarbonates Barnes et al. (1986) suggest that it is due to contribution of organic $\mathrm{CO}_{2}$ from the soil, where micro organisms and the roots of plants produce $\mathrm{CO}_{2}$.

\section{COMPARISON WITH MAGNESITE DEPOSITS FROM OTHER COUNTRIES}

Our stable isotope data plus data from former Yugoslavia (Fallick et al. 1991), Turkey (Zedef et al. 2000) and Poland (Jedrysek \& Halas 1990) are shown and correlated in figure 3.

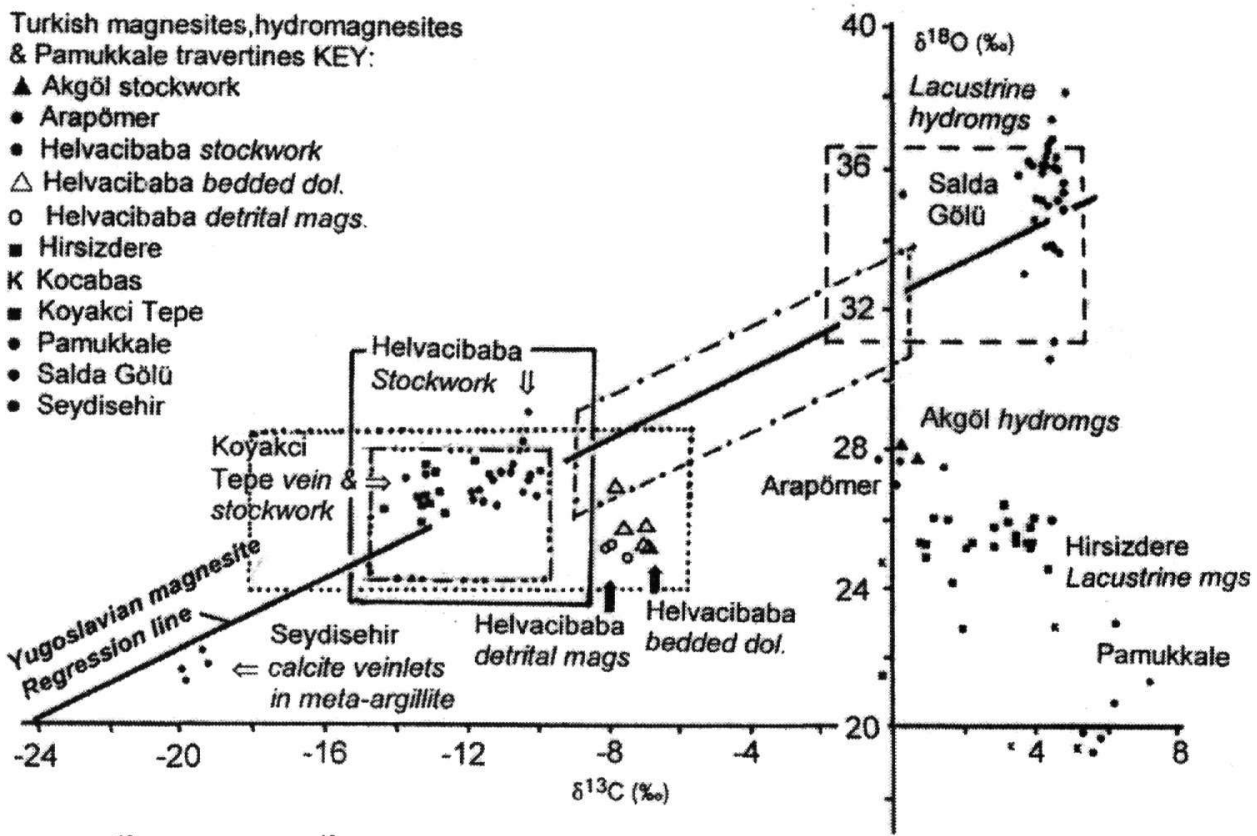

Figure 3. $\delta^{18} \mathrm{O}_{\mathrm{SMOW}}$ versus $\delta^{13} \mathrm{C}_{\mathrm{PDB}}$ diagram with data from Greece, Former Yugoslavia, Poland and Turkey, Greek vein magnesites: field is defined by solid line (square).

Polish vein magnesites: field is defined by dotted line.

Former Yugoslavia vein magnesites: field is defined by dashed line with three dots between.

Former Yugoslavia Lacustrine magnesite (Bella Stena): field is defined by dashed line.

Former Yugoslavia intermediate type: field is defined by dashed line with one dot inbetween.

Turkish magnesites are plotted in the diagram (see KEY for localities-symbols).

The Greek vein magnesites overlap and correlate very well with vein-type magnesites from all three other countries. The field of vein type magnesites is located between the lacustrine magnesite field, shown in the upper right part of the diagram, and the Seydisehir carbonates occurring in meta argillites (rich in organic carbon). According to Zedef et al. (2000) the Seydisehir carbonates and 
the lacustrine magnesites form the two end members of a fluid mixing line, which connects them. In the middle of this mixing line is the field of the vein type magnesite. Zedef et al. (2000) suggest that the negative carbon values are due to the contribution of organic $\mathrm{CO}_{2}$ from the decarboxylation of organic material occurring in the sediments. According to Irwin et al. (1977) this decarboxylation reaction starts at about $70^{\circ} \mathrm{C}$

\section{CONCLUSIONS}

The oxygen isotope compositions of the magnesites from N.Evia, Lesvos and Chalkidiki range from 24.0 to $30.1 \%$, and carbon isotope compositions vary from -8.63 to $-14.85 \%$. Similar isotopic compositions have been reported for similar vein and stockwork type magnesite deposits from: Turkey (Koyakci Tepe, vein and stockwork types; Helvacibaba, stockwork type), Poland (vein type), and Former Yugoslavia (vein type).

These compositions correspond to magnesite values, which are considered to represent isotopic equilibrium with their formation waters.

The fractionation between magnesite and cold meteoric water, estimated from the observed $\delta^{18} \mathrm{O}_{\text {smow }}$ values, is about 35 . A similar fractionation of about 34 at $12^{\circ} \mathrm{C}$ (mean temperature of cold meteoric waters occurring in the peri-Aegean area) was obtained using the equation of $O^{\prime}$ Neil \& Barnes (1971). A fractionation of the same order of magnitude (at $12^{\circ} \mathrm{C}$ ) is suggested from consideration of the compiled 1000.In. $\alpha$ vs $T$ curves (Friedman \& $O^{\prime}$ Neil 1977) for the fractionation of $O^{18}$ between alkaline earth carbonates and water. This is strong evidence that meteoric water is involved in the formation of the magnesite.

Cold waters occurring in the peri-Aegean area contain bicarbonates with $\delta^{13} \mathrm{C}_{\mathrm{PDB}}$ values from 8.0 to $-15.5 \%$ and $\delta^{18} \mathrm{O}_{\text {SMOW }}$ from 24.5 to about $30.0 \%$, which are in the same range with

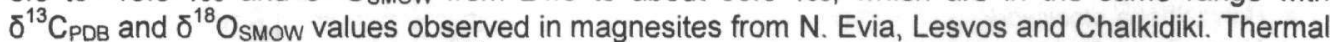
water bicarbonates have similar $\delta^{18} \mathrm{O}_{\text {SMOW }}$ values with magnesite, but different $\delta^{13} \mathrm{C}_{\mathrm{PDB}}$ values. The close isotopic relationship between magnesites and cold-water bicarbonates could indicate that these bicarbonates could be the source of carbon, in such a case carbon is organic from the activities of bacteria and other organisms in the soil. The suggestion of Zedef et al. (2000) for the origin of carbon from decarboxylation reaction at depth is a strong one as well. However, in both cases the interpretation is definitely organic carbon, which is the only carbon source that can give the strongly negative $\delta^{13} \mathrm{C}_{\mathrm{PDB}}$ values.

\section{ACKNOWLEDGEMENTS}

I thank Prof. V. Trommsdorff and V. Dietrich for the availability of the facilities, which made this work possible and for their hospitality during my stay at the Institute of Mineralogy and Petrography of ETH, Zurich. I also thank Dr Gretchen L. Fruch - Green for the valuable discussions and suggestions.

\section{REFERENCES}

Barnes I. \& O'Neil J.R. 1971. Calcium magnesium carbonate solid solution from holocene conglomerate cements and travertines in the Coast Ranges of California. G.C.A., 35, 699-718.

Barnes I., O'Neil J.R., Rapp J. \& White D. 1973. Silica carbonate alteration of serpentine: wall rock alteration in mercury deposits of the Coast Ranges of California. Econ. Geol., 68, 388-398.

Barnes I., Leonis C. \& Papastamataki A. 1986. Stable isotope tracing of the origin of carbon dioxide discharges in Greece. Proc. Int. Symp. Underground water tracing, Athens, 1, 29-43.

Burgath K., Grissemann C., Johannes W., Jung D., Knolke H., Cockel F., Makris J., Mohr M., Mussalam K. \& Raschka H. 1981. On the genesis of magnesite deposits in Northern Greece. Proc. Int. Symp. of Unesco, Project $\mathrm{N}^{\circ} 169$ (Metallogeny of mafic and ultramafic complexes), 3, 226-239.

Capedri S. \& Rossi A. 1973. Conditions governing the formation of ophicalcites and listwanites (Central Evia, Greece). Bull. Geol. Soc. of Greece, 10/2, 278-297.

Capedri S. 1974. Genesis and evolution of a typical Alpine-type peridotite mass under deep-seated conditions (Central Evia, Greece). Boll. Soc. Geol. It., 93, 81-114. 
Craig H. 1963. The isotopic geochemistry of water and carbon in geothermal areas. In: Tongiorgi E. (ed.), Nuclear geology in geothermal areas. Consiglio Nazionale delle Ricerche, Laboratorio de Geologia Nucleare, Pisa, Italy, 17-53.

Dabitzias S. 1980. Petrology and genesis of the Vavdos cryptocrystalline magnesite deposits, Chalkidiki peninsula, Northern Greece. Econ. Geol., 75, 1138-1151.

Dabitzias S. 1981. Additional evidence and a synopsis on the origin of the magnesite deposits in the Vavdos district, Northern Greece. Proc. Int. Symp. of Unesco, project $\mathrm{N}^{\circ} 169$ (Metallogeny of mafic and ultramafic complexes), 3, 269-283.

Emrich K., Ehhalt D.H., \& Vogel J.C. 1970. Carbon isotope fractionation during the precipitation of calcium carbonate. Earth Planet. Sci. Letters, 8, 363-371.

Fallick A., llich M. \& Russell M. 1991. A stable Isotope Study of the magnesite Deposits associated with the Alpine-Type Ultramafic rocks of Yugoslavia. Econ. Geology, 86, 847-861.

Friedman I. \& O'Neil J.R. 1977. Data of geochemistry, $6^{\text {th }}$ ed. Chapter KK: Compilation of stable isotope Fractionation factors of Geochemical interest. Geol. Surv. Prof. Paper, 440-KK.

Gartzos E. 1986. On the genesis of cryptocrystalline magnesite deposits in the ultramafic rocks of N. Evia. Ph.D. thesis, ETH Zurich, $195 \mathrm{p}$.

Gartzos E. 1990. Carbon and oxygen isotope constraints on the origin of magnesite deposits, N. Evia (Greece). S.M.P.M., 70, 67-72.

Gartzos E. \& Stamatis G. 1996. Genesis of the thermal springs of Sperchios graben, Greece. N. Jb. Geol. Paleont., H2, 91-115.

Gartzos E., Migiros G., Serelis K. \& Parharidis I. 1994. The ultramafic rocks of Evia - E. Thessaly and the hosted chromitites. $7^{\text {th }}$ Int. Congress Geol. Soc. Greece, XXX/3, 137-153.

Gat J.R. \& Carmi I. 1970. Evolution of the isotopic composition of atmospheric waters in the Mediterranean Sea area. J. Geophys. Res. 75, 3039-3048.

Guernet C. 1971. Etudes geologiques en Eubee et dans les regions voisins (Grece). Ph.D. thesis, Univ. Paris, $395 \mathrm{p}$.

Illic M. 1968. Problems of the genesis and genetic classification of magnesite deposits. Geologica Carpathica, $\mathrm{XIX}, 1$.

Irwin H., Curtis C. \& Coleman M. 1977. Isotopic evidence for source of diagetic carbonates formed during burial of organic-rich sediments. Nature, 269, 209-213.

Jedrysek M. \& Halas S. 1990. The origin of magnesite deposits from the Polish Foresudetic Block ophiolites: preliminary $\delta^{13} \mathrm{C}$ and $\delta^{18} \mathrm{O}$ investigations. Terra Nova, 2, 154-159.

Le Pichon X. \& Angelier J. 1979. The Hellenic arc and trench system. Tectonophysics, 60, 1-42.

O'Neil J. R. \& Barnes I. 1971. Carbon and oxygen isotopic compositions in some fresh water carbonates associated with ultramafic rocks and serpentinites, W. USA. G.S.A., 35, 687-697.

Papastamataki A. \& Leonis K. 1982. Reports on geochemical exploration of geothermal fields: (I) Area of Lesvos, (II) Area of Platistomo, (III) Area of Edipsos, (IV) Area of Loutraki - Sousaki. I.G.M.E., Athens.

Petrascheck W.E. 1964. Weitere Erkenntnisse uber die Bildung der Lagerstatten des dichten Magnesits und des Meerschaums. Randex-Rdsch, Radenthein, 2, 103-108.

Pohl W. 1990. Genesis of magnesite deposits - models and trends. Geologische Rundschau, 79/2, 291-299.

Serelis K. \& Gartzos E. 1994. The ultramafic rocks of Lesvos. $7^{\text {th }}$ Int. Cong. Geol. Soc. Greece, XXX/3, 113-124.

Zedef V., Russell M., Fallick A. \& Hall A. 2000. Genesis of Vein Stockwork and Sedimentary Magnesite and Hydromagnesite Deposoits in the Ultramafic Terranes of Southwestern Turkey: A Stable Isotope Study. Econ. Geology, 95, 429-446. 